\title{
Why Jesus spoke in parables
}

Author:
Francois P. Viljoen ${ }^{1}$
Affiliation:
'Unit for Reformational
Theology and the
Development of the SA
Society, Faculty of Theology,
North-West University,
Potchefstroom, South Africa
Corresponding author:
Francois Viljoen,
viljoen.francois@nwu.ac.za
Dates:
Received: 23 July 2019
Accepted: 27 Sept. 2019
Published: 26 Nov. 2019
mobrt phone or
How to cite this article:
Viljoen, F.P., 2019, 'Why
Jesus spoke in parables',
In die Skriflig 53(1), a2523.
https://doi.org/10.4102/ids.
v53i1.2523
Copyright:
Co 2019 . The Authors.
Licensee: AOSIS. This work
is licensed under the
Creative Commons
Attribution License.

In the Synoptic Gospels, listeners ask Jesus about the purpose of his parables. These Gospels provide two parallel accounts of this discussion (Mt 13:10-17 // Mk 4:10-12 // Lk 8:9-10 and Mt 13:34-35 // Mk 4:33). The version in Mark 4:10-12 particularly raises problems related to a sharp distinction between the 'mystery' that the 'insiders' understand, and 'parables', which are intended 'so that' the 'outsiders' would not understand, repent and be forgiven. Mark's reference to Isaiah 6:9-10 differs from the Masoretic Text (MT) and Septuagint (LXX) versions, but corresponds with the Aramaic Targum, which reads 'they may be forgiven' instead of 'and I would heal them'. It seems that the Markan Jesus deliberately uses parables to prevent 'those on the outside' from understanding, repentance and forgiveness. Luke retains the 'so that', but does not distinguish between the two groups that sharply, as he refers to 'others' and not 'those on the outside'. He omits Mark's apparent offensive phrase about the prevention of repentance and forgiveness. Matthew smooths out some of these difficulties by changing the 'so that' to 'because'. According to Matthew, Jesus speaks in parables because the people do not see, hear and understand. The reason for their inability to comprehend, is their rejection of Jesus. This article investigates these parallel passages to decipher the meaning within their textual context. The argument of this article is that these parallel statements should be read within the context of the parable of the sower to grasp their meaning.

Keywords: Parable; Mystery; Insider; Outsider; Teacher; Jesus; Parable of the sower.

\section{Introduction}

Although each of Jesus' parables is a self-contained story, ${ }^{1}$ it is only accessible to modern interpreters through written texts. Gerhardsson (1991:325) warns that 'modern expositors can increase their hermeneutic freedom immensely, when they cut the narrative meshalim out of their frames'. In many cases, the parables are framed by introductions ( $\pi \rho \mu_{\mu} \theta^{\prime} \alpha-$ forethoughts) and conclusions ( $\dot{\varepsilon} \pi \mu \eta \theta \dot{i} \alpha$ - afterthoughts) that provide evaluations and interpretations. Though some of these introductions and conclusions may have formed part of an original story, others were added by the evangelists. Such additions determine the interpretation of the story. Comparative frames such as 'as it is [with the situation in the parable], so is it with the kingdom of God / heaven' often form part of such settings.

The parallel passages in Matthew 13:10-17 // Mark 4:10-12 // Luke 8:9-10 and in Matthew 13:3435 // Mark 4:33 form significant interpretive frames, not only for the parable of the sower and Jesus' explanation of the parable, but to a certain extent for all of Jesus' parables. This article investigates these passages that provide an explanation of why Jesus spoke in (a) parable(s). While it seems that the term parable in this context primarily refers to the parable of the sower, the principle applies to similar stories that meet the requirements of the form-critical definition of a parable. The broader context indicates that the term also includes other figurative forms of speech that Jesus used. ${ }^{2}$

\section{The reason for speaking in parables The textual setting of Jesus' explanation}

The explanation of why Jesus spoke in parables follows the parable of the sower in all three Synoptic Gospels (Mt 13:1-9; Mk 4:1-9; Lk 8:4-8). This parable begins Jesus' ministry of proclaiming the Word. The parable tells the story of how seed is sown in different kinds of soil.

1.John included none of these parables. Instead he portrays Jesus as making use of $\pi \alpha p o u$ í $[$ [figures] for example the image of the sheepfold (Jn 10:1-6), the door of the sheepfold (Jn 7-10), the good shepherd (Jn 10:11-18) and the vine and the branches (Jn 15:1-8). Besides the Synoptic Gospels, two non-canonical texts are known to also preserve parables of Jesus, namely the Gospel of Thomas and the Secret Book of James.

2.The evangelists did not identify parables in the exact same way. Proverbs, similes, similitudes and narratives are all sometimes described as parables (cf. Hedrick 2004:8). Scholars most commonly consider parables to be short narrative fiction dramatising a common human experience or some incident from nature to convey a spiritual message (cf. Snodgrass 2008:7-9). 
Only the seed that was sown in the good soil comes up, grows and produces a crop.

This parable is followed by the question Jesus' followers pose about the parables (Mt 13:10-17; Mk 4:10-12; Lk 8:9-10). Jesus responds by explaining that parables demonstrate why not all people are receptive to his ministry of the Word. ${ }^{3}$

Following this answer, Jesus continues by explaining the meaning of the parable of the sower (Mt 13:18-23; Mk 4:13-20; Lk 8:11-15). He tells his followers that the determining factor of the parable is the soil, and not the sower or the seed. The condition of the soil determines whether the seed would grow or not. The parable signifies that only some people would be receptive to Jesus' words. This explanation sheds light not only on the parable of the sower, but also on Jesus' answer as to why he spoke in parables in general.

The parable of the sower can be regarded as the parable about the parables (Hooker 2000:87). This is evident from Jesus' opening words when he starts explaining the parable, 'Don't you understand this parable? How then will you understand any parable?' (Mk 4:13). Mark seemingly regards this introductory parable as key to understanding all Jesus' parables.

As conclusion to the section on the parables, Mark 4:33-34 once again states that Jesus always spoke in parables, a statement that Matthew 13:34-35 takes over with some variation.

\section{That which is given to insiders and outsiders respectively}

Each of the Synoptic Gospels provides accounts of the 'twelve and others' (Mk) // 'disciples' (Mt and Lk) asking Jesus about the purpose of his parables. Jesus' answer varies slightly in each of the Gospels. These significant similarities and variations are indicated in the following Table 1.

\section{To insiders Jesus spoke of mysteries and to outsiders in parables}

According to each of the Synoptic Gospels, Jesus responds

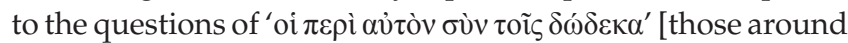
him with the 12] according to Mark // 'oi $\mu \alpha \theta \eta \tau \alpha i$ ' [the disciples] according to Matthew // 'oi $\mu \alpha \theta \eta \tau \alpha i ̀ ~ \alpha v ่ \tau o \tilde{v}^{\prime}$ [his disciples] according to Luke. According to Mark, those who pose the question are people who gathered around Jesus along with the 12. The reference to 'disciples' in Matthew and Luke could refer to the 12 only, but probably also includes a wider group of disciples. What is clear from all three accounts,

3.There are, however, questions about where Mark 4:10-12 (et par.) comes from. This question is based on mainly three issues: Firstly, this passage contains words and expressions that are not characteristic of Mark; secondly, the quotation from Isaiah 6:9-10 corresponds with the Aramaic Targum, which suggests that the passage has its origin in a pre-Markan Aramaic speaking community; and lastly, it seems that this passage pre-supposes reflections on the question why so many refused Jesus' passage pre-supposes reflections on the question why so many refused Jesus message (Hultgren 2000:460; Snodgrass 2008:146). Some scholars are of the opinion that it is a composition of Mark (Bultmann 1968:325; Lambrecht 1981:93-9; Scott 1989:24). Others argue that it comes from a pre-Markan collection of parable (Guelich 2015:200; Schweizer 1983:69). Others argue that it is a traditional unit tha Mark inserted between the parable of the sower and its interpretation (Hultgren 2000:459; Jeremias 1963:18). Yet others claim that whatever the immediate context
of the material in Mark 4:11-12, it is an authentic logion of Jesus (Manson 1957:77). is that those who pose the question are people who are drawn to Jesus' ministry and who have responded by gathering around him. They can be regarded as an inside group. Mark emphasises that this enquiry takes place in privacy, as he

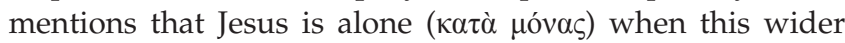
group of disciples posed their question. In Mark's version, the question is not specific and relates to the parables ( $\left.\tau \grave{\alpha} \varsigma \pi \alpha \rho \alpha \beta \mathrm{o} \lambda \alpha \varsigma_{\varsigma}\right)$ in general. In Matthew, the question is

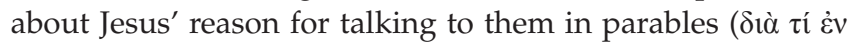

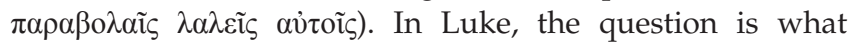
this one parable, the parable of the sower, means

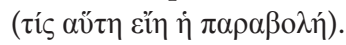

In his response, Jesus then differentiates between the group with him and those on the outside. ${ }^{4}$ In Mark, the outside

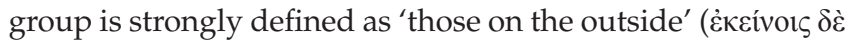

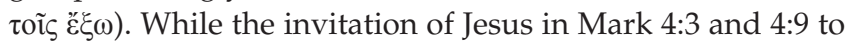
listen, is addressed to everyone: the secret of God's kingdom is only given to those who are prepared to receive it (Hooker

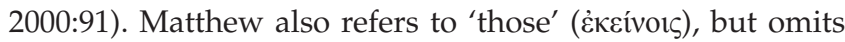
'on the outside'. Luke does not have such a clear distinction between the insiders and outsiders, as he merely refers to 'the

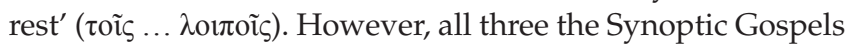
make a distinction between the way Jesus speaks to his disciples and the way he speaks to the others. This signifies different ways in which one can relate to the kingdom, either as an insider or as an outsider (Culpepper 2007:136). It should be noted that the first part of Jesus' answer does not refer to what Jesus does, but to what God does. God provides the inside group with the ability to comprehend the mysteries of Jesus' teachings, while the rest lack this ability. Although the disciples do not understand everything, they have the privilege of receiving additional explanations from Jesus. Mark 4:13 explicitly mentions the disciples' lack of understanding. Yet, they can be taught, while the others lack the ability to comprehend.

It was common practice in the ancient Mediterranean world for teachers to differentiate between how they treat their inner group and how they treat those on the outside. They would usually keep teachings to the outsiders obscure (Keener 1999:378). Diogenes Laertius, a 3rd-century (AD) biographer of the Greek philosophers, mentions how Plato (cf. Diog. Laert. 3.63) and Pythagoras (Diog. Laert. 8.1.15) wished to keep their teachings incomprehensible to outsiders. ${ }^{5}$ It seems that most itinerant Greek teachers preferred to instruct their followers in private, where they gave additional teachings away from the public audience. Although members of the public in some cases would be welcome to attend, special teachings were provided to the 'insiders' as such (Culpepper 1975:112).

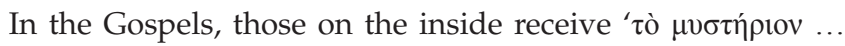

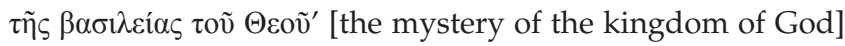

4.A similar distinction is made between those inside and those on the outside of a religious group in 1 Corinthians 5:12, Colossians 4:5 and 1 Thessalonians 5:12.

5.Diogenes Laertius (3:63) writes that 'Plato has employed a variety of terms in order to make his system less intelligible to the ignorant ...' and with regard to Pythagoras, he writes that 'down to the time of Philolaus it was not possible to acquire knowledge of any Pythagorean doctrine, ... and the rest of the Pythagoreans used to say that not all his doctrines were for all men to hear' (Diog. Laert. 8.1.15). 
TABLE 1: Speaking to outsiders and insiders respectively.

\begin{tabular}{|c|}
\hline Mark 4:10-12 \\
\hline 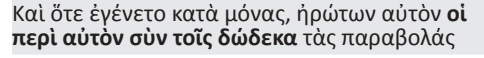 \\
\hline 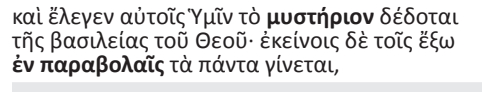 \\
\hline
\end{tabular}

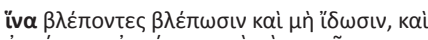

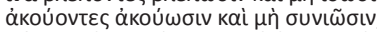

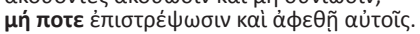

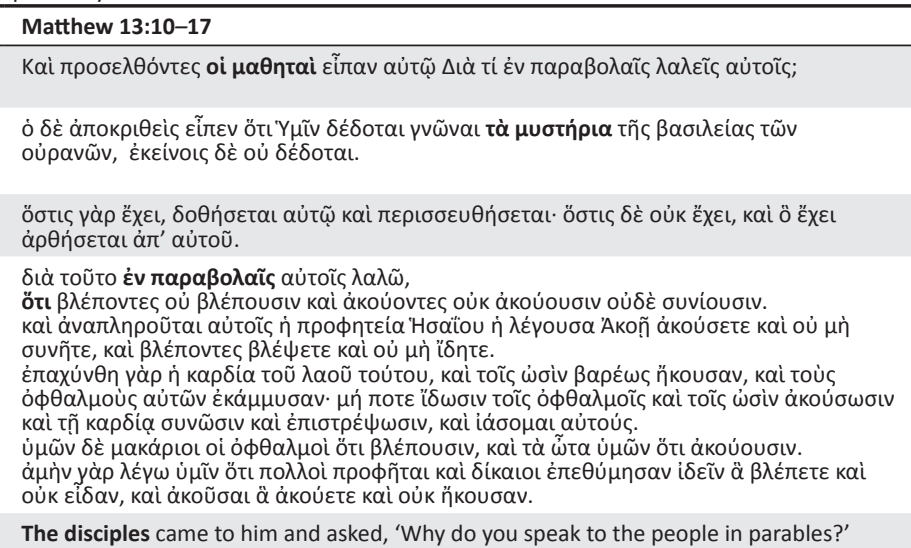

When he was alone, those around him with the 12 asked him about the parables.

He told them, 'The mystery of the kingdom of God has been given to you'. But to those on the outside everything is said in parables

so that 'they may be ever seeing but never perceiving, and ever hearing but never understanding; otherwise they might turn and be forgiven!'

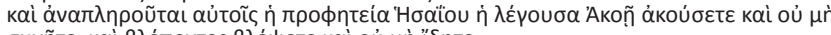

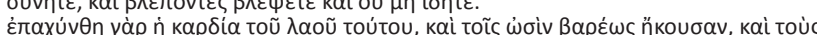

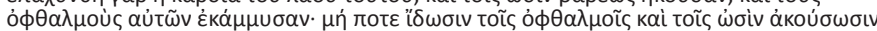

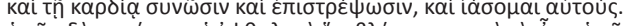

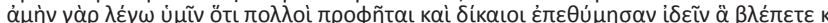
The disciples came to him and asked, 'Why do you speak to the people in parables?'

He replied, 'Because the knowledge of the mysteries of the kingdom of heaven has been given to you, but not to them'.

Whoever has will be given more, and they will have an abundance. Whoever does not have, even what they have will be taken from them.

This is why I speak to them in parables:

Because seeing, they do not see; though hearing, they do not hear or understand.

In them is fulfilled the prophecy of Isaiah: 'You will be ever hearing but never

In them is fulfilled the prophecy of lsaiah. 'You will be ever hearing but never

\section{Luke 8:9-10}

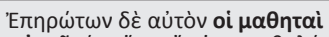

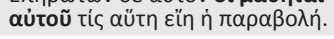

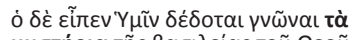

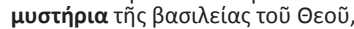
toĩ $\delta \dot{\varepsilon} \lambda$ oเाoĩ

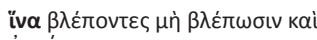

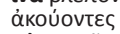

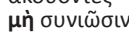

His disciples asked him what this parable meant.

He said, 'The knowledge of the mysteries of the kingdom of God has been given to you, but to others I speak in parables'

understanding; you will be ever seeing but never perceiving. For this people's heart has
become calloused; they hardly hear with their ears, and they have closed their eyes.

become calloused; they hardly hear with their ears, and they have closed their eyes.
Otherwise they might see with their eyes, hear with their ears, understand with their

hearts and turn, and I would heal them.'

But blessed are your eyes because they see, and your ears because they hear. For truly

I tell you, many prophets and righteous people longed to see what you see but did not see it, and to hear what you hear but did not hear it.

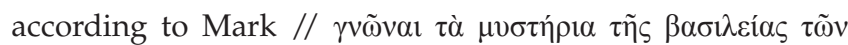
oủpavต̃v [to know the mysteries of the kingdom of heavens]

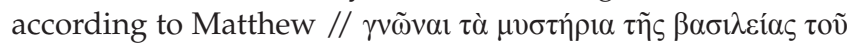
$\Theta \varepsilon o \tilde{v}$ [to know the mysteries of the kingdom of God] according to Luke. Matthew and Luke add the ability to know, while this knowledge is assumed in Mark. ${ }^{6}$ Those who are receptive get to know the mystery or mysteries of the kingdom of God as contained in the parables through Jesus' special teaching. ${ }^{7}$ The requirement for having access to this knowledge is being part of the Jesus' loyal inner group. This group is like the soil that is receptive to the seed. The disciples are in the audience when Jesus speaks in parables, but he provides them with additional explanations of the meaning of the parables when they are together in private. ${ }^{8}$

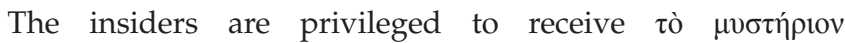
[the mystery] according to Mark // $\tau \grave{\alpha} \mu v \sigma \tau \eta ́ p ı$ [the mysteries] according to Matthew and Luke. While Mark refers to a mystery in the singular, Matthew and Luke refer to mysteries in the plural. The term mystery is only used in this place in the Gospels. ${ }^{9}$ In pagan mystery religions, initiates were given

6.The fact that both Matthew and Luke refer to mysteries in the plural ( and adding the verb 'to know' ( $\gamma v \tilde{\omega} v a \mathrm{~L})$, portions of Matthew 13:11 and Luke 8:10 can be counted among the minor agreements between the two as opposed to Mark (Hultgren 2000:463)

7.The Gospels often refer to Jesus talking to the crowds in parables: 'Jesus spoke all these things to the crowd in parables; he did not say anything to them without usin a parable' (Mt 13:34), for example the father's good gifts (Mt 7:9-11), the wise and the foolish builders (Mt 7:24-27), children in the marketplace (Mt 11:16-19), the sower (Mt 13:1-9), weeds among the wheat (Mt 13:24-30), the mustard seed (Mt 13:31-32) and the leaven (Mt 13:33).

8.The evangelists report that Jesus also spoke to his disciples in parables, for example the treasure in the field (Mt 13:44), pearl of great price (Mt 13:45-46), the dragnet (Mt 13:47-50), the lost sheep (Mt 18:12-14) and the wedding feast (Mt 22:1-14).

9.In the Gospel of Mark, the secret of the kingdom of God is probably related to the 'messianic secret'. secret knowledge and shown secret objects during initiation rituals so they could inherit eternal life (Culpepper 2007:138). A person who experienced $\tau$ ò $\mu v \sigma \tau$ prov was required to take a pledge of silence to ensure that holy secrets would not be disclosed to profane outsiders (Meyer 1992:942). Some Jewish movements believed that God had entrusted Israel with special 'mysteries' (e.g. Test Lv 2:10; Judah 16:4). Some spoke of hidden things, like the laws of creation, being concealed from the rest of humankind (e.g. Dt 29:29; 1 Enoch 4:1-3; $41: 1-8 ; 49: 2 ; 52: 2 ; 59: 1-3 ; 106: 19)$. The righteous would receive teachings about hidden things and mysteries, while these mysteries would remain concealed from the wicked (Wis 2:22; 4 Ezr 14:45-47). The Qumran community believed that revelation occurred in two stages: God inspired the prophets to write, but they did not fully understand what they had written. God then revealed interpretation of mysteries to their 'Teacher of Righteousness' (e.g. $1 \mathrm{QpHab}$ 7.4-5, 13-14). By following his teachings, they would be able to recognise the real meaning of Scriptures. While the Qumran 'Teacher of Righteousness' was said to interpret the Scriptures, Jesus interpreted his own words, being the revelation of the mystery of the kingdom of God (Culpepper 2007:138). Apocalyptic texts often refer to 'mysteries' (e.g. LXX Dan 2:18-19, 28-30, 47; 2 Esdr 14:5; 1 Enoch 63:3; 103:2) to signify hidden eschatological secrets that can be revealed by God alone (Hultgren 2000:454). According to New Testament text, these secrets will be revealed at the end of times, but they have already been disclosed to the inner community (Rm 16:25-26; Eph 3:3-6), ${ }^{10}$ as this divine knowledge is revealed in Christ. This emphasises Jesus' role 10.Paul describes the mystery of God as his plan to redeem Jews as well as Gentiles through the Gospel (Rm 11:25; 16:25; Eph 3:1-9; Col 1:25-27). 
as the revealer of these mysteries. According to Matthew 11:25 and 16:17, Jesus apparently agrees that, until the end of time (cf. Mt 10:26), some truths will only be understood by a special group. ${ }^{11}$ It seems that Jewish people in general shared such understandings (Mt 13:35).

While the parables reveal the mystery of the kingdom, they

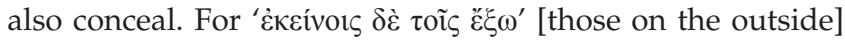

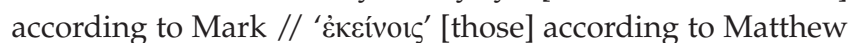

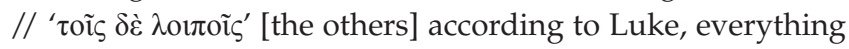
is done ' $\varepsilon$ v $\pi \alpha \rho \alpha \beta 0 \lambda \alpha \tilde{\tau} \varsigma^{\prime}$ [in parables]. Mark's statement makes a sharp distinction between the insiders and outsiders, while the distinction is less sharp in Matthew and Luke. Jesus refers to those who are not receptive to his ministry of the Word as regarded as the bad soil that is not receptive to the seed of the sower in the parable. They are those who reject Jesus such as the scribes and the Pharisees. It was common practice that Jewish leaders would use parables as illustrations to explain what they were teaching (Keener 1999:378). However, if they only gave the illustration without providing the point they were referring to, the illustration remained a riddle (Test Abr 12-13A). This implies that in the context of Jesus' ministry, only persons who knew him were able to understand his parables. For those who rejected him, such as the Pharisees, the parables remained riddles (cf. Mt 12:24-45).

It seems that parables by nature were enigmatic and required explanation (Hultgren 2000:456). In the LXX, the term $\pi \alpha \rho \alpha \beta o \lambda \eta$ refers to a figure of speech of which the meaning is not obvious. In Psalms 78:2 (LXX 77:2), $\pi \alpha \rho \alpha \beta o \lambda \alpha i$ [parables] and $\pi \rho \circ \beta \lambda \eta \mu \alpha \tau \alpha$ [problems] are used in a synonymous parallelism. In Proverbs 1:5-6, $\pi \alpha \rho \alpha \beta$ o $\alpha$ í refer to sayings that require skills to be understood. Parables need interpretation (2 Esdr 4:47; Sir 47:15-17). John also refers to Jesus' figurative speech, which results in his disciples not understanding him (Jn 10:6). The hour would come that Jesus would no longer speak in figures ( $\left.\dot{\varepsilon} \vee \pi \alpha \rho \mu_{1} \alpha 1 \varsigma\right)$ but would tell them 'plainly' $(\pi \alpha \rho \rho \eta \sigma i ́ \alpha)^{12}$ about his Father (Jn 16:25, 29). According to the gnostic Apocryphon of James (8:1-10), a document from the 2nd century CE, Jesus had to spend 18 days after his resurrection with his disciples to explain his parables. In contrast to speaking in parables or in figures, Mark 8:32 describes that, when Jesus tells his disciples of his coming death and resurrection, he does so plainly ( $\pi \alpha \rho \rho \eta \sigma i ́ \alpha)$.

The Synoptic Gospels are clear about Jesus's disciples not always understanding his parables and needing further explanation. The parable of the sower is told in public, but the disciples receive explanation in private ( $\mathrm{Mk} 4: 13-20)$. Jesus speaks in parables by way of public speaking, but then explains what he said in private (cf. Mk 4:33-34; 6:30-31; 7:14-17; 9:28, 33; 10:10; Culpepper 2007:137). In doing so, Jesus unveils the apocalyptic secrets of the coming of God's eschatological reign (Witherington III 2006:263).

11.The private teaching forms part of the secrecy motif according to which the secret of God's coming kingdom is only given to the inner circle of followers (Witherington III 2006 263). Whil the is only givento is promin

12.The contrast between speaking 'in parables' and 'plainly' is also made in Ap. Jas. 7:1-6; Irenaeus, against Heresies, 1.3.1 and Pistis Sophia 1-6.
It was common practice that disciples would ask their rabbis for further explanation, for example as in Tosefta Sanhedrin 7:10 ${ }^{13}$ and the Babylonean Talmud Qiddushin, 31a. ${ }^{14}$ While parables were used as illustration, the rabbis sometimes even used them as secret speech. Some rabbinic traditions also linked the ability to understand with membership to the community of Israel (Keener 1999:379).

Matthew is the only evangelist to insert the statement 'Whoever has will be given more, and they will have an abundance. Whoever does not have, even what they have will be taken from them. ${ }^{\prime 15}$ This statement reinforces the idea that the secrets of the kingdom being given to the disciples are not being given to the crowds. Whatever inkling of understanding they have, would be taken away from them, while the ability of his disciples to understand would be enhanced (Hedrick 2004:33).

\section{Accounted reason: 'So that', or 'because'}

Jesus then proceeds by providing the reason for speaking in parables to outsiders. In the account of Mark 4:12, Jesus

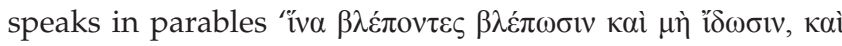

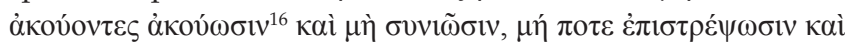

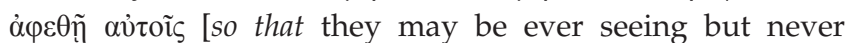
perceiving, and ever hearing but never understanding; otherwise they might turn and be forgiven!]. Jesus quotes Isaiah 6:9-10, which is introduced by the 'so that (iv $\alpha$ )' they do not understand. Otherwise they 'might repent and be forgiven'. The Markan quotation differs from the MT and LXX versions, but corresponds exactly with the Aramaic Targum by including the use of the third person (rather than the second) and the phrase 'they may be forgiven' instead of 'and I heal them' (as in the MT and LXX). In this response lies the difficulty. Why would Jesus deliberately speak in such a way that people would not understand and repent? As mentioned above, this version of the quote creates the impression that this passage may have had its origin in the pre-Markan Aramaic speaking community (Hultgren 2000:460). The easy answer to the problem would be to argue that Mark included this quote from the Targum in an inattentive and clumsy manner, as it does not fit his overall message. However, such an answer is unsatisfactory. Another suggestion to the problem could be that iv $\alpha$ be understood as 'because' (Lampe 1991:189). To soften the offense, one suggestion has been to revert to the Aramaic syntax to weaken the purpose clause. Such a suggestion also does not seem to fit, because it is complemented with the $\mu$ í $\pi$ o $\varepsilon$

13.The Tosefta is a compilation of the Jewish oral law from the late 2 nd century CE, the period of the Mishnah.

14.The Talmud forms one of the primary sources of Jewish religious law and Jewish theology, serving as guide for the daily lives of Jews. The Talmud has two components, the Mishnah (c.200 CE), a written compendium of Rabbinic Judaism's oral Torah, and the Gemara (c.500 CE), an elucidation of the Mishnah and related Tannaitic writings.

15. Mark also uses this statement in Mark 4:25.

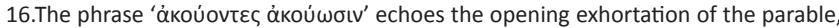

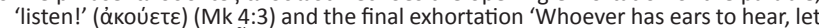

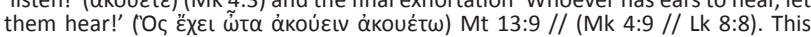
exhortation probably would have evoked in the mind of the audience the Shema of Deuteronomy 6:4-5, but whereas Deuteronomy 6:4-5 requires its hearers to love God with heart and soul and strength, the parable of Jesus calls for wholehearted response to Jesus himself (Hooker 2000:89). 
[otherwise] clause in the same sentence, which clearly expresses purpose in a negative sense. The most obvious meaning of the clause is therefore that the outsiders get a glimpse of the mysteries of the kingdom with the parables, but they do not grasp their full meaning. They are indeed seeing ( $\beta \lambda \dot{\varepsilon} \pi \circ \nu \tau \varepsilon \varsigma \beta \lambda \varepsilon \dot{\pi} \pi \sigma \mathrm{v})$ ) what Jesus does and hearing

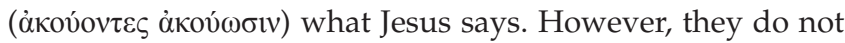

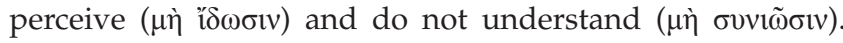
If they indeed do perceive, they will turn and be forgiven.

The Lukan account sounds slightly less offensive, "iv $\alpha$

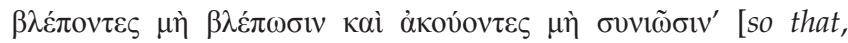
'though seeing, they may not see; though hearing, they may not understand']; Luke 8:10. The Lukan version only contains the first part of the quotation from Isaiah 6 without mentioning 'healing' (as in the MT and LXX), or 'forgiveness' (as in the Aramaic Targum and Mk). Luke omits Mark's comment that the intention of the parables is to condemn those who are not his disciples. Yet, the separation is clear. ${ }^{17}$ Those who resist the parables, those who do not see or hear, will not understand. They are like the rocky or the thorny soil in the parable of the sower. However, it is no longer 'all things' that are in parables to 'those outside' as in Mark, but in Luke Jesus speaks 'parables' to 'others'. Luke's version seems to correlate with his overall perspective, which is that Jesus prepared his disciples with special teachings so that they could become the apostles in the post-Easter era (Hultgren 2000:464). In Acts 28:26-27, Luke once again quotes Isaiah $6: 9$ to illustrate the blindness of Israel and to justify his mission to the gentiles (Ac 28:28).

Matthew's account removes the offensiveness by replacing

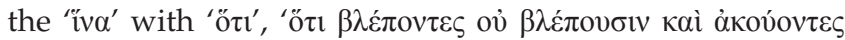

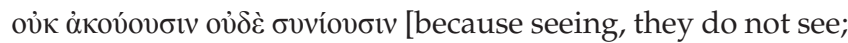
though hearing, they do not hear or understand]. They have an inability to understand on their own account. They deliberately refuse to listen to Jesus. For Matthew, the parable serves a didactic purpose. Jesus tells parables 'because (ö $\tau)^{\prime}$ people do not see, hear and understand' (Hultgren 2000:426). As is typical of Matthew, he expands on the quotation introduced with a fulfilment formula, 'In them is fulfilled' ( $\dot{\alpha} v \alpha \pi \lambda \eta \rho \tilde{\tau} \tau \alpha)$. Matthew's account reminds of Ezekiel 12:2, 'Son of man, you live among rebels who have eyes but refuse to see. They have ears but refuse to hear. For they are a rebellious people', where God commands his prophet to speak to his hard-hearted people in a way that would make it clear that they do not understand (Witherington III 2006:263). With such rebellious people, the parables have the judicial function of demonstrating their broken relationship with God. They must become aware of how ignorant they are about the coming of God's kingdom. For such people, the parables serve as stumbling blocks, similarly to those placed in Israel's path as in Isaiah $6 .{ }^{18}$

17.This separation between insiders and outsiders continues throughout the Gospels and Acts, where Paul repeats the quotation from Isaiah by referring to the Jews in Rome who continue to refuse his message (Ac 28:26-27).

18. Although Isaiah 6:9-10 recounts Isaiah's call, it conveys the prophet's experience with his ministry to Israel as what seemed to be a complete failure to convert his people (Hooker 2000:92)
The Synoptic Gospels all state that the outsiders rejected Jesus with the result that he increasingly turned to his disciples and trained them in private. The disciples are depicted as being capable of learning and understanding. To the crowds, he would only speak in parables with the result that they would not grasp the point of illustration (Witherington III 2006:258). Parables gave insight to those who accepted Jesus, but they came as a judgement to the stubborn ones who rejected him. Therefore, listening attentively becomes a prerequisite for understanding God's revealed mysteries. Jesus offers revelatory wisdom to his open-minded followers. The message is clear: one cannot understand the kingdom of God apart from accepting Jesus, the agent of the kingdom.

The parables provide some explanation as to why so many people of Israel rejected Jesus (Hooker 2000:88). They did not respond to Jesus as they did not understand his teachings. Those who were unable to comprehend the message of Jesus, fulfil the prophecy in Isaiah 6:9-10. This prophecy was central to the early Christian view of why Israel did not accept Jesus (cf. Mk 4:12; Lk 8:10; Jn 12:37-41; Ac 28:26-27; Keener 1999:38). It reflects a common motif in the prophets (e.g. Is 29:9-10; 42:19-20; 43:8; 44:18-19; Ezk 12:2).

However, those who turn to Jesus, will be ‘healed' (Mt 13:15).

\section{Jesus always spoke to the crowds in parables}

Later in the same Markan and Matthean chapters, the evangelists once again refer to Jesus speaking in parables (see Table 2). In Mark it forms the conclusion to the section on Jesus teaching in parables.

Mark 4:33-34 once again distinguishes between how Jesus

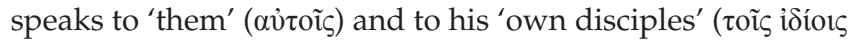
$\mu \alpha \theta \eta \tau \alpha i \varsigma)$. His own disciples have the privilege of receiving explanations for Jesus' earlier teachings. In a similar statement, Matthew defines 'them' as 'the crowds'

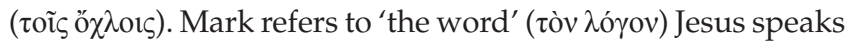
in the parables. It echoes 'the word' that the sower in the parable sows. This implies that the parables are vehicles of the Word, the gospel of the kingdom to which they point

TABLE 2: Jesus always spoke to the crowds in parables.

\begin{tabular}{|c|c|}
\hline Mark 4:33-34 & Matthew 13:34-35 \\
\hline 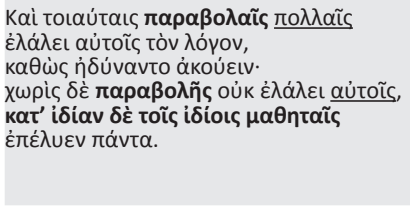 & 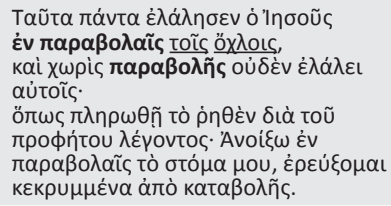 \\
\hline $\begin{array}{l}\text { With many similar parables Jesus spoke } \\
\text { the word to them, } \\
\text { as much as they could understand. } \\
\text { He did not say anything to them without } \\
\text { using a parable. } \\
\text { But when he was alone with his own } \\
\text { disciples, he explained everything. }\end{array}$ & $\begin{array}{l}\text { Jesus spoke all these things to the } \\
\text { crowds in parables; } \\
\text { he did not say anything to them } \\
\text { without using a parable. } \\
\text { So was fulfilled what was spoken } \\
\text { through the prophet: } \\
\text { 'I will open my mouth in parables, } \\
\text { I will utter things hidden since the } \\
\text { creation of the world.' }\end{array}$ \\
\hline
\end{tabular}


(Culpepper 2007:152). Mark qualifies Jesus speaking of the word 'as much as they could understand'. Apparently, this stands in conflict with Mark 4:12. However, in light of this qualification, it is clear that Jesus customised his teaching according to the ability of the people to grasp it. From this, it can be surmised that Jesus did not limit his teaching due to a desire to keep the crowds in the dark, but because they were not able to hear more of his teaching.

Mark proceeds by telling readers that Jesus explained the meaning of the parables to his disciples when they were alone. In Matthew, the distinction between 'them' and the 'disciples' is less prominent, as he only refers to the crowds. Matthew furthermore omits this reference to Jesus' private teaching to his disciples, but adds the formula quotation while quoting from Psalms 78:2 to explain how the parables convey hidden mysteries. ${ }^{19}$ 'So was fulfilled what was spoken through the prophet (ö $\pi \omega \varsigma \pi \lambda \eta \rho \omega \theta \tilde{n} \tau$

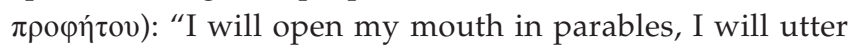
things hidden since the creation of the world"' (Mt 13:35). While Mark states that mysteries are concealed in the parables, Matthew states that the parables convey God's hidden revelations..$^{20}$

\section{Conclusion}

The parable of the sower forms a simile that reflects Jesus' ministry. Jesus spoke in public and the seed of his Word fell on several kinds of soil. In his private clarification of the parable, he explains to his disciples how this parable depicts the way different kinds of people relate to his teachings. Between the parable and the explanation, Jesus answers the question of his followers about the reason why he spoke in parables. His answer reflects the meaning of the parable. Mark and Matthew later both again refer to why Jesus regularly spoke in parables.

Jesus' answer, as retold in all these passages, serves as a commentary on his ministry. Jesus spoke to all those who were receptive to his message, as well as those who rejected him. Those who were receptive to his message were like the good soil. They formed his inner group. They were privileged to receive Jesus' private explanations. During these explanations, Jesus gave the disciples special teachings so that they could recognise the mysteries contained in the parables. The outsiders were considered to have a basic understanding of Jesus's parables, but because of the hardness of their hearts, they did not recognise the significant role of Jesus as apocalyptic teacher. They therefore forfeited the opportunity to have access to Jesus' private teaching and could subsequently not grasp the mysteries contained in the parables.

19. Matthew uses formula quotations to mark important events, such as events related to Jesus' birth (Mt 1:22), his childhood (Mt 2:15), his ministry in Galilee related to Jesus' birth (Mt 1:22), his childhood (Mt 2:15), his ministry in Galilee
(Mt 4:14), his healing miracles (Mt 8:17, quoting from Is 53:4.), and his passion (Mt 12:17; 21:4; 27:9). Matthew regards Jesus' parables of equal importance.

20.In a similar way, Paul refers to the mysteries that God reveals to his followers (1 Cor 2:7-10; Col 2:2-3)
These passages reveal that Jesus' parables can only be perceived as life-changing through faith. The parables as such do not generate faith, as faith is a gift from God. While the parables are often enigmatic, the revelation contained in them is grasped in a miraculous way.

After the earthly ministry of Jesus had ended, the evangelists who received insight into the mysteries contained in the parables, utilised these parables to teach the churches, its leaders and disciples of the mysteries of the parables.

\section{Acknowledgement Competing interest}

The author declares that no competing interest exist.

\section{Author contributions}

I declare that I am the sole author of this research article.

\section{Ethical considerations}

This article followed all ethical standards for a research without direct contact with human or animal subjects.

\section{Funding information}

This research received no specific grant from any funding agency in the public, commercial, or-not-for-profit sectors.

\section{Data availability statement}

Data sharing is not applicable to this article as no new date were created or analysed in this study.

\section{Disclaimer}

The views and opinions expressed in this article are those of the author and do not necessarily reflect the official policy or position of any affiliated agency of the author.

\section{References}

Bultmann, R., 1968, History of the synoptic tradition, rev. edn., Harper \& Row, New York, NY.

Culpepper, R.A., 1975, The Johannine school: An evaluation of the Johannine-school hypothesis based on an investigation of the nature of ancient schools, Scholars Press, Missoula, MT. (Society of Biblical Literature Dissertation Series, 26).

Culpepper, R.A., 2007, Mark, Smyth \& Helwys, Macon, GA.

Gerhardsson, B., 1991, 'If we do not cut the parables out of their frames', New Testament Studies 37(3), 321-325. https://doi.org/10.1017/S0028688500015903

Guelich, R.A., 2015, Mark 1-8:26, vol. 34A, Zondervan, Grand Rapids, MI. (Word Biblical Commentary).

Hedrick, C.W., 2004, Many things in parables: Jesus and his modern critics, Westminster John Knox Press, London.

Hooker, M.D., 2000, 'Mark's parables of the kingdom (Mark 4:1-4)', in R.N. Longenecker (ed.), The challenge of Jesus's parables, pp. 79-101, Eerdmans, Grand Rapids, MI.

Hultgren, A.J., 2000, The parables of Jesus: A commentary, Eerdmans, Grand Rapids, MI. Jeremias, J, 1963, The parables of Jesus, transl. S.H. Hooks, Harper \& Row, New York, NY. Keener, G.S., 1999, A commentary on the Gospel of Matthew, Eerdmans, Grand Rapids, MI.

Lambrecht, J., 1981, Once more astonished: The parables of Jesus, Cross Road, New York, NY 
Lampe, P, 1991, 'iva', in H. Balz \& G. Schneider (eds.), Exegetical dictionary to the New Testament, pp. 188-190, Eerdmans, Grand Rapids, MI.

Manson, W., 1957, 'The purpose of the parables: A re-examination of St. Mark iv.10-12', Expository Times 68(5), 132-135. https://doi.org/10.1177/001452465 706800502

Meyer, M.W., 1992, 'Mystery religions', in D.N. Freedman (ed.), Anchor Bible dictionary, vol. 4, pp. 941-945, Doubleday, New York, NY.
Schweizer, E., 1983, 'The question of the messianic secret in Mark', in C. Tuckett (ed.), The messianic secret, pp. 65-74, Fortress Press, Philadelphia, PA.

Scott, B.B., 1989, Hear then the parable: A commentary on the parables of Jesus, Fortress Press, Philadelphia, PA.

Snodgrass, K.R., 2008, Stories with intent: A comprehensive guide to the parables of Jesus, Eerdmans, Grand Rapids, MI.

Witherington III, B., 2006, Matthew, Smyth \& Helwys, Macon, GA. 